\title{
MANAJEMEN SARANA DAN PRASARANA DINIYAH TAKMILIYAH
}

\section{Supiana}

Universitas Islam Negeri Sunan Gunung Djati Bandung

JI. A.H. Nasution No. 105 Cibiru Bandung

Email: supiana@uinsgd.ac.id

\section{A. Heris Hermawan}

Universitas Islam Negeri Sunan Gunung Djati Bandung

JI. A.H. Nasution No. 105 Cibiru Bandung

Email: herishermawan@uinsgd.ac.id

\section{Muhammad Fawaz Hilmy}

Universitas Islam Negeri Sunan Gunung Djati Bandung JI. A.H. Nasution No. 105 Cibiru Bandung

Email: mfawazhilmy22@gmail.com

\begin{abstract}
ABSTRAK
Diniyah Takmiliyah merupakan lembaga pendidikan non-formal yang terus bergerak mengembangkan pendidikan agama Islam pada masyarakat, upaya memperkuat pemahaman terhadap dasar ilmu agama Islam. Sarana dan prasarana yang kurang memadai menjadi masalah mendasar di Diniyah Takmiliyah pada umumnya. Manajemen sarana dan prasarana yang ada di Diniyah Takmiliyah menjadi penting untuk memaksimalkan penggunaaannya sehingga dapat menciptakan proses pembelajaran efektif dan efisien. Metode penelitian menggunakan pendekatan kualitatif dengan metode deskriptif, dengan teknik pengumpulan data yang digunakan, meliputi: Observasi partisipatif, Wawancara, Studi dokumentasi. Perencanaan sarana dan prasarana Diniyah Takmiliyah direncanakan setiap tahun ajaran baru, pengadaan sarana dan prasarana Diniyah Takmiliyah, inventarisasi di Diniyah Takmiliyah dalam pencatatan barang yang telah diadakan, pemeliharaan sarana dan prasarana di Diniyah Takmiliyah dalam pemeliharaan dan perawatan sarana dan prasarana yang ada, penghapusan sarana dan prasarana di Diniyah Takmiliyah yaitu menghilangkan sarana dan prasarana yang mengalami kerusakan berat.
\end{abstract}

Kata Kunci: Manajemen, sarana prasarana, diniyah takmiliyah.

\section{ABSTRACT}

Diniyah Takmiliyah is a non-formal educational institution that continues to move to develop Islamic religious education in the community, efforts to strengthen understanding of the basic knowledge of Islamic religion. Inadequate facilities and infrastructure became a fundamental problem in Diniyah 
Takmiliyah in general. Management of facilities and infrastructure in Diniyah Takmiliyah is important to maximize their use so that they can create an effective and efficient learning process. The research method uses a qualitative approach with descriptive methods, with data collection techniques used, including: Participatory observation, interviews, documentation studies. Planning of Diniyah Takmiliyah facilities and infrastructure is planned every new school year, procurement of Diniyah Takmiliyah facilities and infrastructure, inventory in Diniyah Takmiliyah in recording goods that have been held, maintenance of facilities and infrastructure in Diniyah Takmiliyah in maintenance and maintenance of existing facilities and infrastructure, removal of facilities and the infrastructure in Diniyah Takmiliyah is to eliminate facilities and infrastructure that have been severely damaged.

Keywords: Management, infrastructure, diniyah takmiliyah.

\section{PENDAHULUAN}

Pendidikan merupakan salah satu usaha meningkatkan kualitas hidup manusia melalui pengembangan potensi yang mereka miliki. Pendidikan bukanlah kegiatan yang sederhana, melainkan kegiatan yang dinamis. Mempertimbangkan adanya dinamika penyelenggaraan pendidikan, maka pendidikan memerlukan manajemen yang baik agar tujuan pendidikan tercapai dengan efektif dan efisien (Badrudin, 2014:1).

Kurang tepatnya pengelolaan pada proses manajemen sarana dan prasarana pendidikan yaitu dalam proses kegiatan perencanaan, pengadaan, inventarisasi, pemeliharaan, serta penghapusan, dapat mempengaruhi kualitas proses pembelajaran yang ada di lembaga pendidikan, oleh karena itu manajemen sarana dan prasrana yang baik sangat penting dalam menciptakan pembelajaran yang efektif dan efisien.

Menurut Jaja dan Amirullah (2013:84) Manajemen sarana prasarana adalah proses pengelolaan terhadap seluruh perangkat, alat, bahan dan fasilitas lainnya yang digunakan dalam sebuah proses kegiatan belajar mengajar sehingga proses kegiatan belajar berjalan secara efektif. Proses manajemen sarana dan prasarana pendidikan erat dengan perencanaan sarana dan prasarana, pengadaan sarana dan prasarana, inventarisasi sarana dan prasarana, pemeliharaan sarana dan prasarana dan penghapusan sarana dan prasarana (Rusdiana, 2015:217) Sebagaimana dalam UU No. 20 Tahun 2003 sisdiknas pasal 45 ayat 1 tentang sarana dan prasarana pendidikan, bahwa: "Setiap satuan pendidikan formal dan nonformal menyediakan sarana dan prasarana yang memenuhi keperluan pendidikan sesuai dengan pertumbuhan dan perkembangan potensi fisik, kecerdasan intelektual, sosial, emosional, dan kejiwaan peserta didik".

Manajemen sarana prasarana menjadi sebuah kegiatan yang mesti dilakukan pada sebuah lembaga pendidikan untuk mendukung keberlangsungan kegiatan belajar mengajar. Keberlangsungan pendidikan sangat memerlukan sarana dan prasarana, dilihat dari peran sarana dan prasrana pendidikan yang sangat penting dalam memperlancar pelaksanaan proses pembelajaran. Harapan yang dibebankan pada dunia pendidikan sangat banyak, di sisi lain dunia pendidikan mempunyai masalah yang menghambat 
dalam pelaksanaan kegiatan belajar mengajar yaitu dalam hal sarana dan prasarana, masalah yang serupa dihadapi oleh lembaga pendidikan Islam seperti Diniyah Takmiliyah yaitu masalah sarana dan prasarana pendidikan yang kurang memadai.

Salah satu syarat keberhasilan belajar adalah tersedianya sarana dan prasarana pendidikan yang cukup. Sarana belajar yang menunjang kegiatan belajar murid bermacam-macam bentuknya, pengelolaan sarana dan prasarana pendidikan baik akan memudahkan murid dalam melakukan aktifitas belajar, murid pun lebih semangat dalam belajar. Sebaliknya, kurangnya sarana belajar akan mengakibatkan murid kurang bersemangat dan kurang bergairah dalam belajar, hal ini tentu saja akan mempengaruhi prestasi belajar murid.

Depdiknas telah membedakan antara sarana pendidikan dengan prasarana pendidikan. Sarana pendidikan didefinisikan sebagai perangkat, peralatan, bahan, perabot yang secara langsung digunakan dalam proses pendidikan seperti gedung, bangku, kursi, papan tulis maupun alat lainnya. Sedangkan prasarana pendidikan didefinisikan sebagai perangkat, peralatan, bahan, perabot yang secara tidak langsung digunakan dalam proses pendidikan seperti lapang sepak bola, taman bunga, pagar dan lain sebagainya. (Jaja dan Amirullah, 2013: 65)

Gambaran bahwa Diniyah Takmiliyah Awaliyah Miftahussalam berada di bawah naungan sebuah lembaga yaitu yayasan Assalam. Diniyah Takmiliyah Awaliyah tersebut sudah cukup dikenal oleh masyarakat Kabupaten Tasikmalaya. Pelaksanaan manajemen sarana dan prasarana di Diniyah Takmiliyah Awaliyah Miftahussalam itu sangat sederhana dikarenakan masih menganut pemahaman dunia pendidikan Pondok Pesantren, tetapi dengan demikian Diniyah Takmiliyah tersebut selalu berusaha menjaga kredibilitas dengan terus berusaha melengkapi sarana dan prasrana pendidikan agar tetap memberikan kepercayaan terhadap masyarakat.

Sarana dan prasarana pendidikan yang tersedia di Diniyah Takmiliyah Awaliyah Miftahussalam belum sepenuhnya berada dalam kondisi yang memadai. Dilihat dari segi kuantitas dan kualitas sarana, seperti kursi yang berjumlah 86 tidak sebanding dengan murid yang berjumlah 96 anak dan dari segi kualitas sarana yang mengalami kerusakan-kerusakan. Kondisi yang demikian, selain akan berpengaruh pada proses belajar mengajar juga akan berdampak pada keengganan orang tua untuk menitipkan anaknya ke Diniyah Takmiliyah tersebut. Hal lain yang ditemukan yaitu dalam proses pelaksanaan manajemen sarana dan prasarana seperti pada proses pengadaan sarana prasarana dan inventarisasi sarana prasarana yang tidak berjalan dengan baik dilihat dari pengadaan sarana dan prasarana yang tidak tentu dan dalam pengkodingan sarana belum ada, sehingga pelaksanaan manajemen sarana dan prasarana belum sepenuhnya berjalan dengan baik. Tetapi meskipun dari segi manajemen sarana dan prasarana kurang baik, Diniyah Takmiliyah Miftahussalam termasuk Diniyah Takmiliyah yang unggul di Kabupaten Tasikmalaya.

\section{KAJIAN TEORI}

Sarana didefinisikan sebagai perangkat, peralatan, bahan, perabot yang secara langsung digunakan dalam proses pendidikan seperti gedung, bangku, 
kursi, papan tulis maupun lainnya. Sedangkan prasarana didefinisikan sebagai perangkat, peralatan, bahan, perabot yang secara tidak langsung digunakan dalam proses pendidikan seperti lapang sepak bola, taman bunga, pagar dan lain sebagainya (Jaja dan Amirullah, 2013: 65). Sarana dan prasarana sebagai komponen yang penting dari keseluruhan kegiatan pembelajaran di satuan pendidikan mempunyai fungsi dan peran dalam pencapaian kegiatan pembelajaran sesuai kurikulum satuan pendidikan (Prastyawan, 2016: 34).

Sarana pendidikan adalah semua peralatan dan perlengkapan yang secara langsung digunakan dalam proses pendidikan, sedangkan prasarana pendidikan adalah mencakup semua komponen yang secara tidak langsung menunjang jalannya pendidikan.

Prasarana pendidikan di sekolah dapat diklasifikasikan menjadi dua macam, yaitu prasarana langsung dan prasarana tidak langsung. Prasarana langsung adalah prasarana yang secara langsung digunakan dalam proses pembelajaran, misalnya ruang kelas, ruang laboratorium, ruang praktik, dan ruang komputer. Prasarana tidak langsung adalah prasarana yang tidak digunakan dalam proses pembelajaran, tetapi sangat menunjang proses pembelajaran, misalnya ruang kantor, kantin sekolah, tanah, dan jalan menuju sekolah, kamar kecil, ruang UKS, ruang kepala sekolah, taman, dan tempat parkir kendaraan (Barnawi, 2012:51).

Menurut Jaja Jahari dan Amirullah (2013: 84) manajemen sarana prasarana adalah proses pengelolaan terhadap seluruh perangkat, alat, bahan dan fasilitas lainnya yang digunakan dalam sebuah proses kegiatan belajar mengajar sehingga proses kegiatan belajar bisa berjalan secara efektif. Manajemen sarana prasarana dapat diartikan kegiatan menata, mulai dari merencanakan kebutuhan, pengadaan, penyimpanan dan penyaluran, pendayagunaan, pemeliharaan, penginvertarisan dan penghapusan serta penataan lahan, bangunan, perlengkapan, dan perabot secara tepat guna dan tepat sasaran.

Sarana dan prasarana perlu didayagunakan dan dikelola dengan baik untuk kepentingan proses pembelajaran. Pengelolaan yang ada dimaksudkan agar dalam menggunakan sarana dan prasarana bisa berjalan dengan efektif dan efisien. Pengelolaan sarana dan prasarana merupakan kegiatan yang sangat penting, karena keberadaannya sangat berpengaruh terhadap sukses tidaknya proses pembelajaran.

Proses manajemen sarana dan prasarana akan berjalan dengan baik, maka dalam proses implementasinya harus didasarkan pada prinsip-prinsip pengelolaan pendidikan adalah sebagai berikut:

1. Efektif

Manajemen sarana prasarana harus dilakukan secara efektif, artinya pengelolaan terhadap sarana dan prasarana harus menyesuaikan dengan tujuan pembelajaran.

2. Efisien

Pengelolaan sarana dan prasarana terkait dengan pembiayaan, oleh karena itu, pengelolaan sarana prasarana harus dilakukan secara efisien sesuai dengan dana dan kemampuan lembaga pendidikan (Jaja Jahari, 2013:84) 
Perencanaan sarana dan prasarana pendidikan merupakan proses perancangan upaya pembelian, penyewaan, peminjaman, penukaran, daur ulang, rekondisi/rehabilitas, distribusi atau pembuatan peralatan dan perlengkapan yang sesuai dengan kebutuhan sekolah. Proses ini hendaknya melibatkan unsur-unsur penting di sekolah, seperti kepala sekolah dan wakilnya, dewan guru, kepala tata usaha, dan bendahara serta komite sekolah. Hal ini dilakukan untuk membuka masukan dari berbagai pihak dan meningkatkan tingkat kematangan dari sebuah rencana (Barnawi, 2012:51). Proses perencanaan ini harus dilakukan dengan cermat dan teliti berkaitan dengan karakteristik sarana dan prasarana yang dibutuhkan, jumlah, jenis, dan kendala (manfaat yang didapatkan), beserta harganya (Rusdiana, 2015: 217). Perencanaan yang matang dapat meminimalisasi kemungkinan terjadi kesalahan dan meningkatkan efektivitas dan efisiensi pengadaan sarana dan prasarana.

Hasil suatu perencanaan akan menjadi pedoman dalam pelaksanaan dan pengendalian, bahkan penilaian untuk perbaikan selanjutnya. Perencanan sarana dan prasarana harus dilakukan dengan baik dengan memerhatikan persyaratan dari perencanaan yang baik. Menurut Barnawi (2012: 53) dalam kegiatan perencanaan sarana dan prasarana pendidikan, ada beberapa persyaratan yang harus diperhatikan, sebagai berikut:

1. Perencanaan pengadaan sarana dan prasarana pendidikan harus dipandang sebagai bagian integral dari usaha peningkatan kualitas belajar mengajar.

2. Perencanaan harus jelas. Untuk hal tersebut, kejelasan suatu rencana dapat dilihat pada hal-hal berikut.

3. Berdasarkan atas kesepakatan dan keputusan bersama dengan pihakpihak yang terlibat dalam perencanaan.

4. Mengikuti pedoman (standar) jenis, kuantitas, dan kualitas sesuai dengan skala prioritas.

5. Perencanaan pengadaan sesuai dengan platform anggaran yang disediakan.

6. Mengikuti prosedur yang berlaku.

7. Mengikutsertakan unsur orangtua murid.

8. Fleksibel dan dapat menyesuaikan dengan keadaan, perubahan situasi, dan kondisi yang tidak disangka-sangka.

9. Dapat didasarkan pada jangka pendek (1 tahun), jangka menengah (4-5 tahun), dan jangka panjang (10-15) tahun

Pengadaan merupakan segala kegiatan yang dilakukan dengan cara menyediakan semua keperluan barang atau jasa berdasarkan hasil perencanaan dengan maksud untuk menunjang kegiatan pembelajaran agar berjalan secara efektif dan efisien sesuai dengan tujuan yang diinginkan. Pengadaan sarana prasarana merupakan fungsi operasional pertama dalam manajemen sarana prasarana pendidikan (Bowang Darmawan, 2014:99).

Pengadaan merupakan serangkaian kegiatan menyediakan berbagai jenis sarana dan prasarana pendidikan sesuai dengan kebutuhan untuk mencapai tujuan pendidikan. Kebutuhan sarana dan prasarana dapat berkaitan dengan jenis dan spesifikasi, jumlah, waktu, tempat, dan harga serta sumber yang dapat dipertanggungjawabkan. Pengadaan dilakukan sebagai bentuk 
realisasi atas perencanaan yang telah dilakukan sebelumnya. Tujuannya untuk menunjang proses pendidikan agar berjalan efektif dan efisien sesuai dengan tujuan yang diinginkan (Barnawi, 2012:60).

Pengadaan sarana dan prasarana merupakan kegiatan yang rawan penyelewengan. Oleh karena itu, agar tidak terjebak dalam penyelewengan para pihak yang terlibat dalam pengadaan sarana dan prasarana harus berpedoman pada etika pengadaan barang/jasa yang telah digariskan Presiden. Berdasarkan Peraturan Presiden No.54 Tahun 2010 Ps 6, etika pengadaan yang harus dipatuhi oleh pihak yang terlibat dalam pengadaan barang/jasa sebagai berikut:

1. Melaksanakan tugas secara tertib, disertai rasa tanggung jawab untuk mencapai sasaran, kelancaran, dan ketepatan tercapainya tujuan pengadaan barang/jasa.

2. Bekerja secara profesional dan mandiri, serta menjaga kerahasiaan dokumen pengadaan barang/jasa yang menurut sifatnya harus dirahasiakan untuk mencegah terjadinya penyimpangan dalam pengadaan barang/jasa.

3. Tidak saling memengaruhi, baik langsung maupun tidak langsung yang berakibat terjadinya persaingan tidak sehat.

4. Menerima dan bertanggungjawab atas segala keputusan yang diterapkan sesuai dengan kesepakatan tertulis para pihak.

5. Menghindari dan mencegah terjadinya pertentangan kepentingan para pihak yang terkait, baik secara langsung maupun tidak langsung dalam proses pengadaan barang/jasa.

6. Menghindari dan mencegah terjadinya pemborosan dan kebocoran keuangan negara dalam pengadaan barang jasa.

7. Menghindari dan mencegah penyalahgunaan wewenang dan/atau kolusi dengan tujuan keuntungan pribadi, golongan, atau pihak lain yang secara langsung atau tidak langsung merugikan negara.

8. Tidak menerima, tidak menawarkan, atau tidak menjanjikan untuk memberi atau menerima hadiah, imbalan, komisi, rabat, dan berupa apa saja dari atau kepada siapa pun yang diketahui atau patut diduga berkaitan dengan pengadaan barang/jasa (Barnawi, 2012:197-198).

Setelah proses pengadaan dilakukan maka proses manajemen sarana dan prasarana selanjutnya ialah proses inventarisasi sarana dan prasarana yaitu salah satu aktivitas dalam pengelolaan perlengkapan pendidikan di sekolah adalah mencatat semua perlengkapan yang dimiliki oleh sekolah. Pencatatan ini disebut dengan istilah inventarisasi perlengkapan pendidikan. Kegiatan tersebut merupakan suatu proses yang berkelanjutan.

Inventarisasi adalah pencatatan dan penyusunan daftar barang milik negara secara sistematis, tertib, dan teratur berdasarkan ketentuan-ketentuan atau pedoman-pedoman yang berlaku (Bafadal, 2014:55). Menurut Keputusan Menteri Keuangan RI Nomor Kep. 225/MK/V/4/1971 barang milik negara adalah berupa semua barang yang berasal atau dibeli dengan dana yang bersumber, baik secara keseluruhan atau sebagiannya, dari Anggaran Pendapatan Belanja Negara (APBN) ataupun dana lainnya yang barang-barangnya di bawah penguasaan pemerintah, baik pusat, provinsi, maupun daerah otonom, baik yang berada di dalam maupun luar negeri 
Proses pendidikan sangat memerlukan sarana dan prasarana. Sementara itu, sarana dan prasarana akan mengalami penyusutan kualitas dari waktu ke waktu. Sejak barang diterima dari penjual atau pemborong, sejak itu pula barang tersebut mengalami penyusutan kualitas. Baik kualitas maupun kuantitas sarana dan prasarana pendidikan akan menurun drastis jika tidak dilakukan upaya pemeliharaannya secara baik. Oleh karena itu, perlu dilakukan upaya pemeliharaan sarana dan prasarana pendidikan yang kontinu.

Kegiatan pemeliharaan terdapat upaya pengurusan dan pengaturan agar sarana dan prasarana tetap dalam kondisi baik dan siap pakai. Upaya pengurusan dan pengaturan harus dilakukan secara terus-menerus dengan tujuan, antara lain (1) mengoptimalkan usia pakai sarana dan prasarana; (2) menjamin sarana dan prasarana agar selalu siap pakai; (3) menjamin ketersediaan sarana dan prasarana yang diperlukan; (4) menjamin keselamatan pengguna sarana dan prasarana. Dalam pemeliharaan sarana dan prasarana ada lima tahapan yang harus diperhatikan oleh pengelola sekolah (Barnawi, 2012: 227).

Penghapusan sarana dan prasarana merupakan kegiatan pembebasan sarana dan prasarana dari pertanggungjawaban yang berlaku dengan alasan yang dapat dipertanggungjawabkan. Secara lebih operasional, proses penghapusan sarana dan prasarana adalah proses kegiatan yang bertujuan untuk mengeluarkan/menghilangkan sarana dan prasarana dari daftar inventaris karena sarana dan prasarana sudah dianggap tidak berfungsi sebagaimana yang diharapkan terutama untuk kepentingan pelaksanaan pembelajaran sekolah.

Barang-barang yang akan dihapus harus memenuhi syarat-syarat tertentu. Menurut Suharsimi Arikunto dan Lia Yuliana (2009: 281-282) dalam Barnawi (2012: 79), barang-barang yang dapat dihapuskan dari daftar inventaris harus memenuhi salah satu atau lebih syarat-syarat di bawah ini:

1. Dalam keadaan rusak berat yang sudah dipastikan tidak dapat diperbaiki lagi atau dipergunakan lagi.

2. Perbaikan akan menelan biaya yang sangat besar sehingga merupakan pemborosan uang Negara.

3. Secara teknis dan ekonomis kegunaan tidak seimbang dengan biaya pemeliharaan.

4. Penyusutan di luar kekuasaan pengurus barang (biasanya bahan kimia).

5. Tidak sesuai lagi dengan kebutuhan masa kini, seperti mesin tulis biasanya diganti dengan IBM atau personal komputer.

6. Barang-barang yang jika disimpan lebih lama akan rusak dan tidak dapat dipakai lagi.

7. Ada penurunan efektivitas kerja, misalnya dengan mesin tulis baru sebuah konsep dapat diselesaikan dalam 5 hari, tetapi dengan mesin tulis yang hamper rusak harus diselesaikan 10 hari.

8. Dicuri, dibakar, diselewengkan, musnah akibat bencana alam, dan lain sebagainya.

Diniyah Takmiliyah merupakan pendidikan keagamaan non-formal yang selama ini terus berjuang membimbing pendidikan agama Islam pada masyarakat, dalam upaya memperkuat keimanan dan ketakwaan mereka agar terbentuk mental spiritual yang kokoh dengan tetap memperhatikan 
perkembangan zaman. Oleh karena itu penelitian menelaah tentang peranan Diniyah Takmiliyah sebagai pusat pengetahuan agama utama bagi masyarakat (Fathor dan Maimun, 2016: 74)

Menurul Nurul Jadid (2013) dalam Fathor dan Maimun (2016: 75) Ditilik dari akar katanya, diniyah dan takmiliyah merupakan perpaduan dari kata AdDin dan Kamil. Kata Ad-Din dimaknai dengan makna keagamaan sedangkan kamil diartikan sebagai yang menyempurnakan. Dari dua stuktur kata yang dijadikan satu tersebut, Diniyah Takmiliyah berarti tempat belajar masalah keagamaan yang menyempurnakan, dalam hal ini agama Islam. Madrasah ini lahir dan berkembang seiring dengan kuatnya kesadaran masyarakat akan pentingnya Pendidikan Agama telah membawa kepada arah pembaharuan dalam Pendidikan.

Menurut Fathor dan Maimun (2016: 78) bentuk dan cirin Diniyah Takmiliyah secara umum, setidaknya ada beberapa karakteristik, diantaranya:

a. Pendidikan Diniyah Takmiliyah (suplemen) yang berada di tengah masyarakat dan tidak berada dalam lingkaran pengaruh pondok pesantren.

b. Pendidikan diniyah yang berada dalam lingkaran pondok pesantren tertentu, dan bahkan menjadi urat nadi kegiatan pondok pesantren.

c. Pendidikan keagamaan yang diselenggarakan sebagai pelengkap (komplemen) pada pendidikan formal di pagi hari.

d. Pendidikan diniyah yang diselenggarakan di luar pondok pesantren tapi diselenggarakan secara formal di pagi hari, sebagaimana layaknya sekolah formal Diniyah Takmiliyah lembaga pendidikan yang memberikan pendidikan dan pengajaran agama secara klasikal.

Menurut Amin dan Ishom (2014: 91) hakikat tujuan didirikannya Diniyah Takmiliyah adalah untuk memberikan pendidikan ilmu-ilmu agama yang cukup kepada para murid lembaga pendidikan yang memberikan pendidikan dan pengajaran agama secara klasikal yang bertujuan untuk memberi tambahan pengetahuan agama Islam kepada anak didik yang merasa kurang menerima pelajaran agama Islam di sekolah di pagi hari.

Mengenai pendidikan diniyah, dalam Peraturan Pemerintah Nomor 55 Tahun 2007 tentang Pendidikan Agama dan Keagamaan dijelaskan bahwa yang dimaksud dengan pendidikan diniyah adalah pendidikan keagamaan Islam yang diselenggarakan pada semua jalur dan jenjang pendidikan. Pendidikan diniyah non formal diselenggarakan dalam bentuk pengajian kitab, Majelis Taklim, Pendidikan al-Qur'an atau bentuk lain yang sejenis.

Menurut Peratutan Menteri Agama Nomor 13 Tahun 2014 Tentang Pendidikan Keagmaan Islam pasal 35 dan 36 bahwasanya standar Sarana dan Prasarana Madrasah Diniyah.

Pasal 35 (1) Satuan pendidikan diniyah formal harus memenuhi persyaratan standar sarana pendidikan sesuai ketentuan peraturan perundangundangan. (2) Selain persyaratan standar sarana pendidikan sebagaimana dimaksud pada ayat (1), satuan pendidikan diniyah formal wajib memiliki masjid dan kitab keislaman sebagai sumber belajar.

Pasal 36 Satuan pendidikan diniyah formal wajib memiliki prasarana pendidikan paling sedikit meliputi lahan, ruang kelas, ruang pimpinan satuan 
pendidikan, ruang pendidik, ruang tata usaha, ruang perpustakaan, ruang laboratorium, dan prasarana lainnya yang diperlukan dalam rangka proses pembelajaran.

Peraturan di atas menjelaskan bahwa standar sarana dan prasarana yang harus dimiliki oleh Madrasah Diniyah, yaitu:

1. Lahan;

2. ruang kelas;

3. ruang pimpinan satuan pendidikan;

4. ruang pendidik;

5. ruang tata usaha;

6. ruang perpustakaan.

Peraturan di atas tidak menentukan standar khusus sarana dan prasarana yang harus penuhi oleh sebuah lembaga pendidikan Islam non formal seperti Diniyah Takmiliyah, peraturan di atas hanya menyebutkan sarana dan prasarana yang harus

\section{METODE PENELITIAN}

Langkah-langkah yang akan dilakukan dalam penelitian ini meliputi: 1) Menentukan pendekatan dan metode penelitian, 2) Menentukan jenis dan sumber data penelitian, 3) Menentukan tempat pengumpulan data penelitian, 4) Menentukan teknik pengumpulan data penelitian, 5) Menentukan teknik analisis data penelitian, 6) Menentukan uji keabsahan data penelitian. Penelitian ini menggunakan metode deskriptif kualitatif, yaitu metode yang bertujuan untuk mendeskripsikan masalah yang terjadi atau berlangsung secara rinci apa adanya. Menurut Sugiyono (2012:9) Metode penelitian kualitatif adalah metode penelitian yang berlandaskan pada filsafat positivisme, digunakan untuk meneliti pada kondisi objek yang alamiah, di mana peneliti adalah sebagai instrumen kunci, teknik pengumpulan data dilakukan secara triangulasi, analisis data bersifat induktif/kualitatif, dan hasil penelitian kualitatif lebih menekankan makna dari pada generalisasi.Penulis menggunakan tipe penelitian deskriptif untuk memberi gambaran secara jelas mengenai masalahmasalah yang diteliti yaitu tentang Manajemen Sarana Prasarana Diniyah Takmiliyah, dalam pelaksanaannya peneliti mengumpulkan, mengklarifikasi data, kemudian sebagaimana adanya.

\section{HASIL DAN PEMBAHASAN}

\section{Perencanaan Sarana dan Prasarana di Diniyah Takmiliyah}

Proses perencanaan sarana dan prasarana di Diniyah Takmiliyah Awaliyah Miftahussalam Tasikmalaya dilakukan dengan sederhana melalui rapat atau musyawarah yang dihadiri oleh Kepala Diniyah, Kepala Yayasan dengan para Guru juga melibatkan pihak yang berkaitan dari masyarakat setempat. Diniyah Takmiliyah Awaliyah Miftahussalam Tasikmalaya biasanya menyampaikan perencanaan sarana dan prasarana untuk tahun ajaran baru kepada pihak-pihak yang berkaitan yang nantinya membantu dalam masalah dana, apa saja yang akan direncanakan untuk setahun ke depan dan apabila terdapat kekurangan-kekurangan yang masih terjadi pada tahun sebelumnya maka akan dilakukan evaluasi dan rencana yang tidak terlaksana pada tahun sebelumnya dimasukan ke dalam rencana setahun ke depan bertujuan agar 
dapat memenuhu kebutuhan sarana dan prasarana di tahun yang lalu seperti kursi murid dan meja murid.

Perencanaan sarana prasarana dilaksanakan pada akhir tahun pembelajaran yaitu dengan bermusyawarah yang dilakukan dengan pihak Diniyah Takmiliyah, dengan mengikuti standar jenis yang ada dan kualitas yang sesuai dengan skala prioritas. Perencanaan pengadaan sarana dan prasarana disesuaikan dengan dana yang ada di Diniyah Takmiliyah, perencanaan dianalisis sesuai dengan kebutuhan yang ada di Diniyah Takmiliyah Awaliyah Miftahussalam. Perencanaan sarana dan prasarana dilakukan untuk memenuhi kebutuhan yang belum terpenuhi atau memperbaiki yang sudah mengalami kerusakan, berharap nantinya dapat menciptakan sarana dan prasarana yang memadai dan menunjang proses pembelajaran di Diniyah Takmiliyah.

Diniyah Takmiliyah Awaliyah Miftahussalam biasanya melakukan pengadaan dan perbaikan sarana dan prasarana di akhir tahun pembelajaran sehingga pada awal tahun ajaran baru, sarana yang telah selesai sudah dapat dipakai, tidak semua dapat dilakukan pada akhir tahun karena disesuaikan dengan dana yang ada. Diniyah Takmiliyah Awaliyah Miftahussalam hanya bisa melakukan pengadaan dan perbaikan yang berskala kecil seperti perbaikan kursi, perbaikan meja, pengecatan, perbaikan pintu, perbaikan dinding, dan sebagainya. Pengadaan dan perbaikan sarana dan prasarana belajar sendiri seperti kursi dan meja disesuaikan dengan dana bantuan yang ada, karena untuk perbaikan dibutuhkan dana yang cukup besar.

Rencana ke depan Diniyah Takmiliyah Awaliyah Miftahussalam salah satunya akan menambah bangunan lagi untuk melengkapi kekurangan ruangan kelas, sekarang baru terdapat 4 kelas yaitu kelas 1 sampai 4 saja yang seharusnya untuk memenuhi standar nasional Diniyah Takmiliyah menambah 2 kelas menjadi 6 kelas. Perencanaan sarana prasarana di Diniyah Takmiliyah Awaliyah Miftahussalam didasarkan pada kebutuhan dalam penggunaan sarana dan prasarana yang dirumuskan jangka pendek, jangka menengah, dan jangka panjang (2.a.W.1 Sumber Kepala Diniyah Takmiliyah, Tanggal 20 April 2018).

Perencanaan di Diniyah Takmiliyah Awaliyah Miftahussalam Tasikmalaya dilakukan melalui musyawarah oleh kepala Diniyah Takmiliyah dengan para guru yang melibatkan pihak-pihak yang bersangkutan. Perencanaan ini dilakukan untuk menentukan kebutuhan sarana prasarana yang dibutuhkan di Diniyah Takmiliyah Awaliyah Miftahussalam Tasikmalaya. Menurut Barnawi (2012:52) Perencanaan hendaknya melibatkan unsur-unsur penting di sekolah, seperti kepala sekolah dan wakilnya, dewan guru, kepala tata usaha, dan bendahara serta komite sekolah. Hal ini dilakukan untuk membuka masukan dari berbagai pihak dan meningkatkan tingkat kematangan dari sebuah rencana. Perencanaan sarana prasarana di Diniyah Takmiliyah Awaliyah Miftahussalam Tasikmalaya sesuai dengan teori Barnawi tersebut, yaitu dengan mengadakan rapat atau musyawarah terlebih dahulu yang melibatkan unsur-unsur penting di Diniyah Takmiliyah, seperti Kepala Diniyah Takmiliyah dengan dewan guru dan juga pihak yang terkait, karena dengan diadakan rapat Kepala Diniyah Takmiliyah dapat menyampaikan beberapa perencanaan kepada masyarakat dan membuka masukan apabila terdapat kekurangan dalam masalah pembangunan pada tahun sebelumnya. Dengan 
adanya rapat atau musyawarah dapat merencanakan sarana dan prasrana yang lebih matang yang akan membantu dalam pengadaan sarana dan prasarana sehingga dapat meminimalisasi kemungkinan terjadinya kesalahan dalam pembangunan ke depanya karena akibat dari kesalahan yang dilakukan efektivitas dan efisiensi akan menjadi rendah dari berbagai segi seperti dana yang membengkak.

Hasil perencanaan yang dilakukan di Diniyah Takmiliyah Awaliyah Miftahussalam Tasikmalaya akan menjadi pedoman dalam pelaksanaan dan pengendalian, bahkan penilaian untuk perbaikan selanjutnya. Diniyah Takmiliyah Awaliyah Miftahussalam Tasikmalaya sudah melakukan kegiatan dengan melengkapi persyaratan pendidikan sesuai dengan yang disyaratkan dalam Depdiknas (2009:8-9) yaitu perencanaan dipandang integral dari usaha peningkatan kualitas belajar mengajar dan perencanaan harus jelas seperti tujuan dan sasaran atau target, di mana kepala Diniyah Takmiliyah Awaliyah Miftahussalam Tasikmalaya selalu berusaha untuk memenuhi sarana prasarana agar proses belajar mengajar berjalan dengan baik. Tujuan dan sasaran atau target yang harus dicapai pun harus jelas termasuk jenis dan bentuk tindakan yang akan dilaksanakan, petugas pelaksana, bahan dan peralatan yang akan dipakai, sampai kapan dan di mana kegiatan dilaksanakan pun harus jelas. Selanjutnya ada kesepakatan bersama dalam hal perencanaan sarana prasarana dengan beberapa pihak seperti Kepala Diniyah Takmiliyah, guru, dan komite yang mengikuti pedoman yang sudah ada sesuai dengan skala prioritas, juga mengikutsertakan orangtua siswa dalam rapat dan pelaksanaan yang didasarkan pada jangka pendek (1 tahun), jangka menengah dan jangka panjang.

\section{Pengadaan Sarana dan Prasarana di Diniyah Takmiliyah}

Proses pengadaan sarana prasarana di Diniyah Takmiliyah Awaliyah Miftahussalam Tasikmalaya dilakukan dengan menyediakan semua keperluan barang, benda, alat, bagi keperluan dalam belajar mengajar dengan cara membeli, produksi sendiri, penerimaan hibah, penyewaan, peminjaman, pendaurulangan, penukaran, rekondisi dan lain sebagainnya. Proses pengadaan sarana dan prasarana dilaksanakan oleh pengurus yang telah diberikan tugas dengan pengawasan Kepala dan dibantu oleh semua pihak Diniyah Takmiliyah.

Proses pengadaan sarana prasarana di Diniyah Takmiliyah Awaliyah Miftahussalam biasanya dilakukan setiap satu tahun sekali pada tahun ajaran baru tetapi karena keterbasan dana dan harus menunggu proses yang lama akhirnya dilaksanakan jika sudah ada barang yang rusak dan sangat dibutuhkan maka baru dilakukan proses pengadaan barang. Biaya yang minim sangat menghambat proses pengadaan sarana dan prasarana, sehingga banyak pengadaan yang tidak terlaksana.

Proses pengadaan sarana prasarana di Diniyah Takmiliyah Awaliyah Miftahussalam tidak terlepas dari yang namanya dana, untuk memperoleh dana tersebut pihak Diniyah Takmiliyah sering mendapat bantuan dari masyarakat sekitar yang sudah menjadi donatur tetap dan pihak Diniyah Takmliliyah juga tidak cuma hanya menunggu bantuan dan hibah melainkan mengajukan surat yang biasanya berbentuk proposal kepada Kementrian Agama. 
Berdasarkan hasil pengamatan penulis dalam penelitian di Diniyah Takmiliyah Awaliyah Miftahussalam Tasikmalaya kaitannya dengan manajemen sarana dan prasrana penulis menemukan hasil penelitian yang berkaitan dengan proses pengadaan yang diadakan tergantung kepada kerusakan sarana dan kebutuhan yang mendesak harus dilaksanakan pengadaan sarana sprasarana dan dilaksanakan oleh semua pihak yang sudah ditentukan dan disepakati. (3.a.W.1 Sumber Kepala Diniyah Takmiliyah, Tanggal 20 April 2018).

\section{Tabel 1}

Pengadaan Sarana Prasarana

\begin{tabular}{|c|l|c|c|}
\hline No & \multicolumn{1}{|c|}{$\begin{array}{c}\text { Pengadaan } \\
\text { Sarana Prasarana }\end{array}$} & Pelaksanaan & Keterangan \\
\hline 1. & Gedung & - & - \\
\hline 2. & Meja & Tidak ditentukan & Tergantung kebutuhan \\
\hline 3. & Kursi murid & Tidak ditentukan & Tergantung kebutuhan \\
\hline 4. & Alat Kebersihan & - & Tergantung kebutuhan \\
\hline 5. & Perbaikan sarana & 1 tahun sekali & Tahun ajaran baru \\
\hline 6. & Buku guru \& murid & 1 tahun sekali & Tahun ajaran baru \\
\hline 7. & $\begin{array}{l}\text { Sarana yang } \\
\text { lainnya }\end{array}$ & - & Tergantung kebutuhan \\
\hline
\end{tabular}

Pengadaan di Diniyah Takmiliyah Awaliyah Miftahussalam Tasikmalaya dilaksanakan berdasarkan kebutuhan sarana dan prasarana yang dibutuhkan dipertimbangkan dengan dana yang ada. Jika jumlah dana memungkinkan maka dilakukanlah pengadaan sarana dan prasarana. Dana untuk pengadaan sarana dan prasarana bersumber dari donatur tetap juga bantuan dari Kementrian Agama, dan iuran orang tua murid biasanya cukup untuk mengadakan barang walaupun dengan merekondisi atau memperbaiki sarana, Diniyah Takmiliyah Awaliyah Miftahussalam Tasikmalaya lebih mengandalkan dana hibah masyarakat dan bantuan dari Kementrian Agama.

Dalam kegiatan pengadaan sarana prasarana Diniyah Takmiliyah Awaliyah Miftahussalam Tasikmalaya dipegang oleh petugas yang ditunjuk oleh Kepala Diniyah Takmiliyah tetapi dalam pelaksanaanya dibantu oleh semua pihak termasuk guru-guru yang ada dengan arahan dan pengawasan dari Kepala Diniyah Takmiliyah. Kegiatan pengadaan sarana prasarana ini bertujuan untuk menyediakan sarana dan prasarana pendidikan yang dibutuhkan untuk menunjang proses belajar mengajar dan meningkatkan hasil pembelajaran.

Pengadaan sarana prasarana di Diniyah Takmiliyah Awaliyah Miftahussalam Tasikmalaya dengan cara pembelian dan produksi sendiri. Menurut Barnawi (2012:60-63) ada beberapa cara pengadaan sarana dan prasarana pendidikan yaitu pembelian, produksi sendiri, penerimaan hibah, penyewaan, peminjaman, pendaurulangan, penukaran, dan rekondisi/ rehabilitasi. Cara yang dilakukan di Diniyah Takmiliyah Awaliyah Miftahussalam Tasikmalaya yaitu dengan cara pembelian, produksi sendiri dan rekondisi.

Pembelian dilakukan dengan menyerahkan sejumlah uang kepada penjual untuk memperoleh sarana dan prasarana sesuai dengan kesepakatan kedua belah pihak, cara ini merupakan cara yang sangat mudah, namun semua 
menggunakan dana yang terbilang terlalu mahal. Selain itu ada juga produksi sendiri dengan cara Diniyah Takmiliyah tidak harus membeli tetapi dengan memproduksi sendiri jika itu memungkinkan. Cara ini akan sangat efektif jika dilakukan untuk memenuhi kebutuhan sarana prasarana, produksi sendiri dapat dilakukan secara massal sehingga tidak hanya memenuhi kebutuhan Diniyah Takmiliyah sendiri tetapi dapat dijual ke madrasah lain. Cara ini dapat melatih kreativitas dan juga melatih jiwa kewirausahaan dan yang terakhir pihak Diniyah Takmiliyah mengadakan sarana dan prasarana dengan cara rekondisi yaitu memperbaiki sarana dan prasrana yang mengalami kerusakan yang ringan sehingga masih dapat diperbaiki dengan cara ini Diniyah Takmiliyah dapat meminimalisir biaya yang dikeluarkan untuk pengadaan berbeda dengan pembelian yang terbilang mahal.

\section{Inventarisasi Sarana dan Prasarana di Diniyah Takmiliyah}

Pelaksanaan inventarisasi di Diniyah Takmiliyah Awaliyah Miftahussalam terbilang sangat sederhana dan masih belum baik dilihat dari tidak adanya data mengenai inventarisasi. Kepala Diniyah beralasan karena jarangnya proses pengadaan sarana dan prasaran yang dilakukan sehingga berpengaruh pada proses inventarisasi sarana dan prasarana juga. Dalam pemberian koding Diniyah Takmilyah Awaliyah Miftahussalam hanya memberikan kode sederhana bertujuan untuk menandai bahwa sarana dan prasarana yang bertanda itu milik Diniyah Takmiliyah Awaliyah Miftahussalam, karena sudah sering kehilangan barang seperti kursi dan menja yang dipinjam oleh masyarakat sekitar dan tidak sedikit yang tidak dikembalikan lagi dengan pemberian kode tersebut maka ada bukti untuk mengambil kembali sarana yang telah dipinjamkan tersebut.

Pihak yang bertanggungjawab dalam inventarisasi di Diniyah Takmiliyah Awaliyah Miftahussalam Tasikmalaya yaitu petugas yang sudah ditentukan oleh Kepala Diniyah Takmiliyah. Proses inventarisasi atau pencatatan dibagi ke dalam 2 bagian yaitu inventaris kelas dan inventaris madrasah. Inventaris kelas yang bertanggungjawab yaitu guru kelas di mana semua dicatat oleh guru kelas yang dirangkum lalu diserahkan kepada Kepala Diniyah Takmiliyah yang nantinya menjadi inventaris madrasah, sedangkan yang bertanggungjawab dalam inventaris madrasah yaitu Kepala Diniyah Takmiliyah. Teknik yang digunakan dalam pencatatannya masih menggunakan teknik manual yaitu petugas mencatatnya pada papan inventaris dan buku inventaris.

Barang-barang yang ada akan dicatat dan disalin dalam buku pencatatan. Inventaris kelas dicatat oleh wali kelas masing-masing, dan inventaris madrasah dicatat oleh petugas dari pengurus Diniyah Takmiliyah. Pencatatan dilakukan guna menghindari hal-hal yang tidak diinginkan. Berikut data inventaris kelas dan inventaris Diniyah Takmiliyah Awaliyah Miftahussalam Tasikmalaya (4.a.W.1 Sumber Kepala Diniyah Takmiliyah, Tanggal 20 April 2018).

Tabel 2

\section{Inventaris Kelas}

\begin{tabular}{|c|l|c|}
\hline No & \multicolumn{1}{|c|}{ Nama Barang } & Jumlah \\
\hline 1. & Meja Guru & 4 \\
\hline 2. & Kursi Guru & 4 \\
\hline 3. & Meja Murid & 25 \\
\hline 4. & Kursi Murid & 50 \\
\hline
\end{tabular}




\begin{tabular}{|c|l|c|}
\hline No & \multicolumn{1}{|c|}{ Nama Barang } & Jumlah \\
\hline 5. & Papan Tulis & 4 \\
\hline 6. & Bangku & 12 \\
\hline 7. & Penghapus & 4 \\
\hline 8. & Sapu & 4 \\
\hline 9. & Ember & 2 \\
\hline 10. & Lap Pel & 2 \\
\hline 11. & Jam Dinding & 4 \\
\hline 12. & Jadwal Piket & 4 \\
\hline 13. & Jadwal Pelajaran & 4 \\
\hline 14. & Pengki & 1 \\
\hline
\end{tabular}

Tabel 3

Inventaris Diniyah Takmiliyah

\begin{tabular}{|c|l|c|}
\hline No & \multicolumn{1}{|c|}{ NamaBarang } & Jumlah \\
\hline 1. & Gedung / Ruang Kelas & 4 \\
\hline 2. & Ruang Guru & 1 \\
\hline 3. & Ruang Kepala & 1 \\
\hline 4. & Masjid & 1 \\
\hline 5. & Perpustakaan & 1 \\
\hline 6. & WC & 25 \\
\hline 7. & Meja Murid & 50 \\
\hline 8. & Kursi Murid & 12 \\
\hline 9. & Bangku & 4 \\
\hline 10. & Meja guru & 4 \\
\hline 11. & Kursi guru & 2 \\
\hline 12. & Kursi tamu & 1 \\
\hline 13. & Meja tamu & 1 \\
\hline 14. & Komputer & 1 \\
\hline 15. & Printer & 1 \\
\hline 16. & Rak buku & 1 \\
\hline 17. & Sound Sistem & 1 \\
\hline 18. & Meja kepala & 1 \\
\hline 19. & Kursi kepala & 1 \\
\hline 20. & Sepeda Motor & \\
\hline
\end{tabular}

Inventarisasi yang dilakukan di Diniyah Takmiliyah Awaliyah Miftahussalam Tasikmalaya dilakukan oleh petugas, guru dan pengurus Diniyah Takmiliyah. Guru mencatat semua perlengkapan yang ada di kelas yang disebut inventaris kelas dan nanti diserahkan kepada kepala Diniyah Takmiliyah yang disebut inventaris sekolah. Menurut Bafadal (2014:57) barang-barang disekolah diklasifikasikan menjadi dua macam, yaitu barang inventaris dan bukan barang inventaris. Barang inventaris seperti kursi, meja, buku, papan tulis, dan perabot lain yang digunakan secara terus menerus dan barang bukan inventaris seperti kapur, kertas, dan barang yang statusnya tidak jelas. Barangbarang inventaris dicatat dalam buku induk inventaris dan buku golongan inventaris, sedangkan barang bukan inventaris dicatat didalam buku induk 
bukan inventaris. Di Diniyah Takmiliyah Awaliyah Miftahussalam Tasikmalaya sudah dilakukan walaupun belum sepenuhnya sesuai dengan yang dikemukakan Bafadal (2014:57) yang seharusnya semua catatan inventaris ada di guru untuk inventaris kelas dan catatan inventaris madrasah ada di Kepala Diniyah Takmiliyah itu belum sepenuhnya terlaksana karena masih banyak sarana dan prasarana yang belum tercatat bahkan tidak dicatat sama sekali dalam buku inventaris, sehingga banyak barang-barang yang hilang begitu saja.

Dalam pemberian koding sarana dan prasaran dilakukan oleh petugas yang pada pelaksanaannya dibantu oleh pengurus Diniyah Takmiliyah belum sesuai dengan standar yang seharusnya menurut Barnawi (2012: 68) kode yang digunakan untuk melambangkan nama atau uraian kelompok atau jenis barang adalah berbentuk angka bilangan numerik yang tesusun dengan polatertentu, agar mudah dan dikenali, pada umumnya nomor kode barang tediri dari 7 buah angka yang tersusun menjadidua bagian yang mana masingmasing berjumlah tiga dan empat angka sedangkan pemberian kode di Diniyah Takmiliyah Awaliyah Miftaussalam hanya dengan memberikan tanda saja dengan yang bertujuan untuk menandai bahwasanya barang yang berkode itu adalah milik Diniyah Takmiliyah Awaliyah Miftahussalam Tasikmalaya.

Inventarisasi merupakan salah satu komponen yang sangat penting dalam proses manajemen sarana dan prasarana dengan berbagai teori yang menunjang untuk menerapkan inventarisasi sarana dan prasarana tetapi kenyataan dilapangan inventarisasi sangatlah sulit untuk diterapkan dan diimplementasikan terutama di lembaga pendidikan non formal seperti Diniyah Takmiliyah, karena budaya pendidikan yang belum berorientasi pada pembukuan dan pencatatan yang baik, inventarisasi sarana dan prasarana akan berjalan dengan baik apabila pihak lembaga pendidikan mengerti dan paham akan pentingnya inventarisasi, bahwa dengan inventarisasi sarana dan prasaran akan dapat melindungi dari hal-hal yang tidak diinginkan seperti pencurian, perusakan dan lain sebagainya.

\section{Pemeliharaan Sarana dan Prasarana di Diniyah Takmiliyah}

Pemeliharaan sarana dan prasarana di Diniyah Takmiliyah Awaliyah Miftahussalam Tasikmalaya pengurus dan petugas dengan melibatkan seluruh warga Diniyah Takmiliyah melakukan perawatan secara rutin seperti pembersihan kaca, lantai, meja, dan kursi serta toilet, pembersihan ruangan dan halaman dari sampah, melakukan pengecatan bangunan dan melakukan pembinaan kepada murid agar mereka sadar dan merasa memiliki akan sarana prasarana yang ada di Diniyah Takmiliyah dalam membantu proses pemeliharaan karena para murid dapat menjaga dan merawat sarana dan prasarana yang ada seperti menrawat barang milik mereka sendiri. Adapun perawatan darurat dilakukan jika terjadi kerusakan sarana prasarana yang tak terduga sehingga pengurus harus segera melakukan perbaikan supaya kerusakan tidak bertambah parah dan proses pembelajaran tidak terganggu.

Sarana dan prasarana yang ada supaya berfungsi dan dapat digunakan dengan baik tanpa banyak menimbulkan gangguan atau hambatan, maka sarana prasarana tersebut perlu dilakukan pengawasan atau pengecekan untuk menghindari adanya pengganggu atau perusak, dengan demikian pihak Diniyah Takmiliyah tahu keadadan terahir sarana dan prasarana yang mereka miliki. 
Pengecekan yang dilakukan pihak Diniyah Takmiliyah terhadap sarana prasarana yang ada di Diniyah Takmiliyah Awaliyah Miftahussalam Tasikmalaya tersebut yaitu dengan cara menunjuk seseorang untuk bertanggungjawab dalam merawat sarana prasarana dan kemudian disepakati oleh bersama. Dalam perawatan sarana prasarana ini tidak dibebankan kepada orang tersebut karena dalam pelaksanaanya satu sama lain saling membantu.

Hasil dari pengamatan pengecekan ini biasanya dilakukan oleh guru pengajar bidang studi karena pada dasarnya guru sering berada di ruangan belajar sehingga dapat mengetahui kondisi sarana dan prasarana apa saja yang dibutuhkan perawatan untuk proses belajar mengajar di Diniyah Takmiliyah, kemudian guru melaporkan kepada petugas yang ditunjuk untuk bertanggung jawab tentang pemeliharaan dan perawatan sarana dan prasarana. Dalam hal ini perlengkapan harus bisa dibedakan atas dua jenis yaitu: barang habis pakai, seperti kapur tulis dan barang tidak habis pakai seperti kursi dan meja dengan begitu dapat dilakukan langkah-langkah apakah kemudian diperlukan pemeliharaan dan perawatan (5.a.W.1 Sumber Kepala Diniyah Takmiliyah, Tanggal 20 April 2018).

Selama melakukan penelitian di Diniyah Takmiliyah Awaliyah Miftahussalam Tasikmalaya dapat dianalisis bahwa pemeliharaan dilakukan dengan baik dan terkelola dengan baik, dari melakukan penyadaran kepada murid akan pentingnya penjaga sarana dan prasrana hingga mengajak untuk menjaga kebersihan dan memelihara kenyamanan kelas, namun ada hal-hal yang masih menjadi hambatan yaitu dalam perawatan barang-barang eletronik belum ada yang bisa merawat dengan baik seperti komputer dan sound sistem yang rata-rata pengurus dan guru hanya bisa menggunakan saja tetapi tidak mengerti dalam masalah perawatanya, maka haruslah diperhatikan dalam mengadakan barang harus ada yang ahli dalam merawat barang sehingga memudahkan dalam proses pemeliharaanya.

Tabel 4

Pemeliharaan Sarana Prasarana

\begin{tabular}{|c|l|l|l|}
\hline No & \multicolumn{1}{|c|}{$\begin{array}{c}\text { Jenis Sarana dan } \\
\text { Prasarana }\end{array}$} & \multicolumn{1}{|c|}{ Penanggungjawab } & \multicolumn{1}{|c|}{ Keterangan } \\
\hline 1. & Ruang kepala & Petugas & Dibantu kepala \\
\hline 2. & Ruang guru & Petugas & Dibantu guru \\
\hline 4. & Ruang perpustakaan & Petugas & Dibantu murid \\
\hline 5. & WC/Toilet & Petugas & Semua pihak \\
\hline 7. & Meja dan Kursi & Petugas & Semua pihak \\
\hline 8. & Alat Kebersihan & Petugas & Semua pihak \\
\hline
\end{tabular}

Pemeliharaan di Diniyah Takmiliyah Awaliyah Miftahussalam Tasikmalaya dilakukan oleh petugas dengan dibatu oleh semua warga Diniyah Takmiliyah, semua warga Diniyah Takmiliyah ikut andil dalam pemeliharaan dan perawatan sarana dan prasarana seperti kebersihan kelas, kebersihan toilet dan seluruh lingkungan Diniyah Takmiliyah. Murid di beri penyadaran bahwasanya barang yang ada di Diniyah Takmiliyah adalah milik semua sehingga haruslah dijaga dengan cara digunakan dengan baik dan benar. untuk menjaga kelas dari orang-orang yang berniat merusak sarana dan prasrana petugas diberi tugas pada setiap pagi sebelum masuk untuk membuka pintu dan sore untuk menutup pintu. Menurut Barnawi (2012: 227-255) ada lima 
tahapan yang harus diperhatikan yaitu pertama penyadaran dengan menanamkan kepada seluruh warga pentingnya sarana prasarana, perlu ditanamkan rasa memiliki sekolah dan menyadarkan kebiasaan baik kepada semua guru dan siswa, kedua pemahaman kepada stakeholder tentang program pemeliharaan sarana dan prasarana dan hal penting yang berkaitan dengan kebiasaan warga sekolah, ketiga pengorganisasian yang diatur dengan jelas siapa yang bertanggungjawab, siapa yang melaksanakan, dan siapa yang mengendalikan, pengorganisasian melibatkan Kepala Diniyah Takmiliyah, guru, siswa, komite sekolah, dan tim teknis pemeliharaan, keempat pelaksanaan mencakup membersihkan semua komponen di dalam maupun di luar ruangan dan merapikan letak benda-benda, kelima pendataan dilakukan untuk menginventarisasi sarana prasarana terkait dengan ketersediaan dan kondisinya.

Pemeliharaan di Diniyah Takmiliyah Awaliyah Miftahussalam Tasikmalaya sebagian besar pelaksanaannya pemeliharaan sesuai dengan teori Barnawi (2012: 227-255) dari penyadaran sampai pendataan dilakukan, mulai dari menanamkan rasa memiliki terhadap sekolah, kebiasaan warga sekolah, pengorganisasian yang sudah diatur dengan jelas, membersihkan sarana di dalam dan di luar yang dilakukan setiap hari, sampai pendataan yang mengetahui sarana prasarana yang baik dan rusak yang nantinya akan dilakukan perbaikan. Perbaikan dilakukan tergantung kerusakan apabila ada kerusakan ringan maka akan langsung diperbaiki dan tidak menunggu kerusakan berat.

Pemeliharaan atau perawatan jika dilaksanakan dengan baik dan benar akan berdampak pada kefektifan dan keefisienan dalam pendayagunaan sarana dan prasarana dengan memberikan umur atau usia sarana dan prasrana menjadi awet tahan lama dan tidak mudah rusak sehingga mengurangi biaya untuk masalah kerusakan saran dan prasarana, hal ini dilakukan cukup oleh Diniyah Takmiliyah Awaliyah Miftahussalam dengan menyadarkan guru dan murid akan pentingnya menjaga sarana milik sendiri otomatis mengikutsertakan seluruh pihak dalam menjaga dan memelihara sarana dan prasrana.

\section{Penghapusan Sarana dan Prasarana di Diniyah Takmiliyah}

Penghapusan sarana dan prasarana di Diniyah Takmiliyah Awaliyah Miftahussalam Tasikmalaya dilakukan dengan mengeluarkan atau menghilangkan sarana dan prasarana dari daftar inventaris karena sarana dan prasarana sudah dianggap tidak dapat dipakai, sudah tidak berfungsi dan tidak bisa diperbaiki lagi. Dilakukan dengan melihat kerusakan terlebih dahulu, jika masih bisa diperbaiki maka dilakukan perbaikan tetapi jika sudah rusak berat dan memerlukan biaya yang besar dalam perbaikannya maka barang tersebut dihapuskan dari inventaris.

Penghapusan sarana dan prasarana di Diniyah Takmiliyah Awaliyah Miftahussalam Tasikmalaya dilakukan dengan cara membuang, menjual dan tukar tambah, di mana sarana prasarana yang sudah tidak bisa dipakai dan diperbaiki di buang, dan yang masih dapat dipakai tetapi memerlukan biaya yang besar dalam pemeliharaan dijual atau ditukar tambah dengan barang yang sesuai dengan kebutuhannya. Diniyah Takmiliyah Awaliyah Miftahussalam selalu melakukan perbaikan secara langsung apabila mendapat 
laporan yang rusak dan tidak membiarkan sarana prasarana sampai rusak berat sehingga penghapusan sangat jarang sekali dilakukan (6.a.W.1 Sumber Kepala Diniyah Takmiliyah, Tanggal 20 April 2018).

Penghapusan yang dilakukan di Diniyah Takmiliyah Awaliyah Miftahussalam Tasikmalaya dilakukan dengan membuang, menjual dan tukar tambah. Sarana prasarana yang sudah rusak berat sehingga tidak dapat diperbaiki dan jika diperbaiki harus memerlukan biaya yang besar. Menurut Suharsimi Arikunto dan Lia Yuliana (2009:281-282) dalam Barnawi (2012:79), barang-barang yang dapat dihapuskan dari daftar inventaris harus memenuhi salah satu atau lebih syarat-syarat yaitu : (a) Dalam keadaan rusak berat, (b) Perbaikan akan menelan biaya yang sangat besar, (c) Secara teknis dan ekonomis kegunaan tidak seimbang dengan biaya pemeliharaan, (d) Tidak sesuai lagi dengan kebutuhan masa kini, (e) Barang-barang yang jika disimpan lebih lama akan rusak dan tidak dapat dipakai lagi, dan (f) Dicuri, dibakar, diselewengkan, musnah akibat bencana alam, dan lain sebagainya.

Penghapusan sarana dan prasarana di Diniyah Takmiliyah Awaliyah Miftahussalam Tasikmalaya sudah sesuai dengan teori yaitu dengan melakukan pertimbangan terlebih dulu sebelum dilakukannya penghapusan barang dengan pertimbangan itulah langkah penghapusan yang dilaksanakan akan menjadi tindakan terbaik dalam proses manajemen sarana dan prasarana. Diniyah Takmiliyah juga terlebih dahulu mengecek kondisi barang, apakah barang sudah rusak berat atau barang belum rusak berat ini bertujuan supaya tidak terjadi kesalahan dalam melakukan tindakan seperti menghapuskan barang yang masih bisa diperbaiki atau masih dapat digunakan yang nantinya hanya akan menimbulkan kerugian.

Proses penghapusan dalam teori terlihat sangat mudah dilakukan yaitu dengan membuang dan menghapus nama barang dari buku inventaris tetapi faktanya dilapangan tidak semudah itu, dalam penghapusan banyak pertimbangan-pertimbangan yang harus diperhatikan dan analisis-analisis yang harus dilakukan guna meminimalisir kesalahan dalam memberikan tindakan pada sarana dan prasarana yang akan melalui proses penghapusan sehingga dengan hal yang kecil seperti itu dapat menciptakan manajemen sarana dan pasarana yang efektif dan efisien.

\section{SIMPULAN}

Perencanaan sarana dan prasarana Diniyah Takmiliyah Awaliyah Miftahussalam Tasikmalaya dilakukan melalui rapat atau musyawarah Kepala Diniyah Takmiliyah dengan dewan guru dan melibatkan pihak yang terkait. Pihak Diniyah Takmiliyah menyampaikan perencanaan pada awal tahun pembelajaran kepada masyarakat terutama masalah bangunan.

Pengadaan sarana dan prasarana Diniyah Takmiliyah Awaliyah Miftahussalam Tasikmalaya hasil dari perencanaan yang sebelumnya dilakukan, pengadaan tidak terlepas dari biaya, dana bersumber dari donatur tetap, Kementrian Agama, Pemerintah Daerah, dan iuran orang tua murid. Pengadaan sarana prasarana dilakukan dengan pembelian, produksi sendiri dan rekondisi barang yang belum rusak berat.

Pemeliharaan sarana dan prasarana Diniyah Takmiliyah Miftahussalam Awaliyah Tasikmalaya dilakukan dengan menunjuk seorang petugas yang 
bertanggung jawab dan dibantu oleh semua pihak dalam pelaksanaannya. Semua warga Diniyah Takmiliyah menjaga dan memelihara sarana dan prasarana yang ada karena seluruh sarana dan prasarana.

Inventarisasi sarana dan prasarana Diniyah Takmiliyah Miftahussalam Awaliyah Tasikmalaya dibagi menjadi dua macam yaitu inventaris kelas dan inventaris madrasah dengan menentukan barang inventaris dan non inventaris, menggunakan sistem manual. Pemberian koding sarana dan prasarana masih sebatas pemberian label.

Penghapusan sarana dan prasarana Diniyah Takmiliyah Awaliyah Miftahussalam Tasikmalaya dengan membuang, menjual dan tukar tambah, barang yang rusak berat dan sudah tidak bisa diperbaiki di buang, barang yang sudah tidak sesuai dengan pembelajaran dijual dan barang yang bisa diperbaiki tetapi memerlukan pemeliharaan yang berat di tukar tambah.

\section{REFERENSI}

Badrudin. (2013). Dasar-dasar Manajemen. Bandung: Alfabeta.

(2014). Manajemen Peserta Didik. Jakarta: Indeks.

Bafadal, Ibrahim. (2014). Manajemen Perlengkapan Sekolah (Teori dan Aplikasi). Jakarta: Bumi Aksara.

Barnawi \& M. Arifin, (2012). Manajemen Sarana dan Prasarana Sekolah, Jogjakarta: Ar-Ruzz Media.

Darmawan, Bowang. (2014). Manajemen Sarana dan Prasarana Pendidikan dalam Meningkatkan Kualitas Pendidikan. Online. diakses 14/02/2018

Haedari, Amin \& Ishom (2004). Pesantren dan Madrasah Diniyah. Jakarta: Diva Pustaka.

Jahari, Jaja. (2013). Pengelolaan Pendidikan. Bandung: Fajar Media.

Jahari, Jaja \& Amirulloh (2013). Manajemen Madrasah. Bandung: Alfabeta.

Moleong (2011). Metodologi Penelitian Kualitatif. Bandung: PT. Remaja Rosadakarya.

Peratutan Menteri Agama Nomor 13 Tahun 2014 Tentang Pendidikan Keagmaan Islam.

Peraturan Pemerintah Nomor 55 Tahun 2007 tentang Pendidikan Agama dan Keagamaan

Prastyawan (2016). Manajemen Sarana dan Prasarana Pendidikan. Jurnal Studi Keislaman AL HIKMAH, Vol. 6, Nomor 1, Maret.

Rachman, Fathor \& Maimun (2016) Madrasah Diniyah Takmiliyah sebagai Pusat Pengetahuan Agama Masyarakat Pedasaan. Jurnal 'Anil Islam. Vol 9 No. 1

Rusdiana (2015). Pengelolaan Pendidikan. Bandung: Pustaka Setia.

Sugiyono (2012). Metode Penelitian Kuatitatif Kualitatif dan R\&D. Bandung: Alfabeta.

Undang-undang No. 20 Tahun 2003 tentang Sistem Pendidikan Nasional. 